\title{
Heavy Metals (Cr, Cd And Ni) Concentrations in Sewage Sludge and Bioaccumulation By Californian Earthworms in the Process of Vermicomposting
}

\author{
Aušra Zigmontienè, Indre Liberytė \\ Department of Environmental Protection, Vilnius Gediminas Technical University, Vilnius and LT-10223 Lithuania
}

\begin{abstract}
Sewage sludge treatment and utilization is an important issue for biodegradable waste management strategy. Heavy metals in sewage sludge complicates its use. One of the ways to improve characteristics of the sewage sludge and to reduce the residual concentrations of heavy metals at the same time is vermicomposting.

Study of heavy metals (Chromium, Nickel and Cadmium) concentrations changes when vermicomposting sewage sludge was performed using Californian earthworms (Eisenia fetida). The bioaccumulation of these heavy metals in earthworms body tissues was studied throughout the whole vermicomposting process. For the study there were $60 \mathrm{~kg}$ of sewage sludge taken from the Vilnius city waste water treatment plant and $1.5 \mathrm{~kg}$ of Californian earthworms were inserted into it. Optimal conditions for earthworms to survive and to work (optimum temperature, moisture, $\mathrm{pH}$ ) were maintained throughout all the time of the study. Duration of the study - 70 days, it was conducted in June - August and samples of sewage sludge and earthworms were taken every 10 days. The parametres of composting sewage sludge were monitored - total carbon, moisture, $\mathrm{pH}$. Concentrations of heavy metals in sewage sludge and in body tissues of earthworms were measured using atomic absorption spectroscopy.
\end{abstract}

Keywords: Sewage sludge; Californian earthworms; vermicomposting; heavy metals.

\section{Introduction}

Currently one of the wastes management problems in Lithuania is neutralization and utilization of sludge in water treatment process. For many years this problem has not been solved adequately and there are huge amounts of sewage sludge in wastewater treatment facilities today. About 80 thousand tons of sewage sludge is generated in Lithuania every year and the largest part of this amount is still stored in wastewater treatment sites. Wastewater treatment plants are not able to sort out such quantities of waste. Moreover, with the increase of wastewater treatment efficiency, technologies' perfection, and more strict environmental standards, the amounts of sewage sludge vill increase as well. Thus, sewage sludge management problem becomes more relevant.

Sewage sludge storage sites is the most popular sludge management method in Lithuania and it raises a number of environmental problems. This kind of sludge treatment is a serious environmental problem as the rotting sludge releases methane gas $\left(\mathrm{CH}_{4}\right)$, hydrogen sulphide $\left(\mathrm{H}_{2} \mathrm{~S}\right)$, and a lot of chemical compounds with unpleasant odor that pollute the environment - decomposing sewage sludge also releases ammonia gas $\left(\mathrm{NH}_{3}\right)$, methylamine $\left(\mathrm{CH}_{3} \mathrm{NH}_{2}\right)$, and other compounds. The amount of sewage sludge generated in wastewater treatment plants is high so the level of emissions is high too [1-2]. Also soil, groundwater or surface water contamination is possible while storing sewage sludge in sites. For sludge storage sites must be installed so that the liquid portion of the sludge could not penetrate through the protective layer and get in soil or groundwater. Sludge storage requires large areas of land that could be used for other needs. It is therefore necessary to look for sewage sludge treatment and recovery methods that not only reduce environmental problems, but also help to solve them.

Sewage sludge is rich in useful organic substances, such as nitrogen, phosphorus, potassium [3]. It is urban waste with a large amount of nutrient that can be recycled into useful nutritional products [4]. One third of sewage sludge is used in agriculture. One of the most important criteria for evaluating the suitability of sewage sludge for agriculture, besides the

Corresponding author: Indrè Liberytè. E-mail address: indre.liberyte@gmail.com http://dx.doi.org/10.3846/enviro.2014.069

(C) 2014 The Authors. Published by VGTU Press. This is an open-access article distributed under the terms of the Creative Commons Attribution License, which permits unrestricted use, distribution, and reproduction in any medium, provided the original author and source are credited. 
biological contamination and harmful organic compounds, is heavy metals. High content of heavy metals in the sludge is a strong argument against the use of sludge for fertilization purposes [5]. The use of treated sewage sludge in agriculture can be very helpful in solving problems, such as improvement of deteriorating soil and land using treated sludge as fertilizer. However, use of sewage sludge is very limited because of high concentrations of heavy metlas and microbiological contaminants [3].

Vermicomposting is one of the most effective organic soldi waste treatment methods turning them into useful and environmentally friendly product. This technology is emerging as a potential option of solid organic waste management. It is an attractive and cost - effective recycling process, tht does not require a lot of capital and energy costs. Vermicomposted wastes are converted into substrate that is useful for plants and soil and reduces the negative environmental impact. [6-7].

Vermicomposting - a special form of composting - is a mesophilic process, caused by microorganisms and earthworms wich decompose organic waste into organic and inorganic materials. The process is faster than ordinary composting, as the material (organic waste) passes through the digestive system of earthworms and they are transformed. Because of this transformztion there are a lot of microbial activity and plant growth regulators in earthworms ${ }^{6}$ manure. The result of vermicompsitng is a substrate that has accumulated chemical pest repellents [8-9]. In addition, studies have shown that all the vermicompost' nutrients were in readily accessible form, also plant nutrient uptake was increased. Vermicompost has a higher content of beneficial nutrients - nitrogen, phosphorus, potassium, calcium, magnesium - than in the subsoil or normal compost product [10].

Earthworms form one of the major macrofauna among soil biota to maintain dynamic equilibrium and regulate soil fertility. Their existence depends on adequate moisture, soil texture, $\mathrm{pH}$, electrolyte concentration, and food source in the given ecosystem. This clearly indicates the interdependency of the environmental factors to the survival of earthworms; when such conditions are created, they further contribute to soil fertility through their activity. Urbanisation brings prosperity but at the same time creates environmental problems like pollution, accumulation of solid waste and poor sanitation. Vermicomposting is an innovative technology for the treatment of wastewater sludge. The efficient potential of earthworms in bioaccumulation of heavy metals in their tissues serves as ecological indicator of soil contaminants.

Heavy metal toxicity and the danger of their bioaccumulation in the food chain represent one of the major environmental and health problems of our modern society. Concentrations of heavy metals in sewage sludge decreases in the process of vermicomposting. Studies have shown that the heavy metals such as chrome, cadmium, nickel, zinc and others were accumulated in earthworms' body tissues [9, 11-13]. And our study examined the bioaccumulation of cadmium, chrome and nickel in earthworms' body tissues and changes of concentration of these metals in sewage sludge. This experiment lasted for 120 days. Concentrations of heavy metals and the removal of these toxic substances from sewage sludge were determined and analyzed.

\section{Materials and Methods}

Quantity of sewage sludge: it has to be a sufficient amount of food provided for earthworms to survive in this study. It is known that the optimal feed and earthworm density is $0.75 \mathrm{~kg}$ food / $\mathrm{kg}$ of earthworms / day [14]. It is estimated that for a kilogram and a half of worms would be enough $60 \mathrm{~kg}$ of sewage sludge throughout the study period (4 months).

Sewage sludge preparation: mechanically dewatered sludge, generated in Vilnius city wastewater treatment plant was selected for the research. Municipal sewage sludge with a moisture content of $70 \%$, is placed in the plastic box with the dimensions of 70x50x60 cm. There are holes drilled in the bottom of the box so the sludge liquid would drain and in the top to ensure adequate aeration and oxygen content. The inside of container agro textile is lined

Indertion of heavy metals: concentrations of heavy metals in sewage sludge of Vilnius wastewater treatment plant are not high. They do not exceed the permitted levels. Therefore heavy metals solution are inserted into sewage sludge. Heavy metals solutions $-\mathrm{CdSO}_{4}, \mathrm{Cr}\left(\mathrm{NO}_{3}\right)_{3}$ ir $\mathrm{Ni}\left(\mathrm{NO}_{3}\right)_{2}$ mixed with destilled water - are prepared and inserted.

Acclimatization and insertion of vermiculture: Vermiculture - Californian earthworms - is inserted in the container with sewage sludge, lot. Eisenia fetida. This earthworm species is chosen for easy insertion into the environment, the efficient and rapid organic waste recycling, reduced sensitivity to environmental fluctuations. Before inserting earthworms into the sewage sludge acclimatization is conducted (Shamyaa 2010). The process is carried in a $42 \times 30 \times 22 \mathrm{~cm}$ diemnsion box divided into two sections. First section is the living environment of earthworms. It is compost made up of cow dung, straw, organic waste residues. The second section - the sewage sludge with heavy metals solutions mix. The box is covered with a lid to prevent direct sunlight. When earthworms from the original enivironment (first section) begin to migrate to the second section, they are inserted into sewage sludge with heavy metals. Then the box is covered with a lid and store in a cool and dark place.

Conditions required for effctive vermicomposting: the whole vermicomposting process is monitrored and optimal environmental conditions are maintained to ensure the useful work of earthworms. In particular, the proper moisture (about 70 percent) is ensured. if the moisture content is reduced, the sludge is watered. The excess of moisture is also controlled. In more than $90 \%$ moisture content, part of the liquid is removed.

For mesophilic process the sewage sludge temperature within $20 \pm 30^{\circ} \mathrm{C}$ is held. Periodically the temperature of sewage sludge is measured and recorded its changes. For useful vermicomposting $\mathrm{pH}$ should be close to neutral, it is of 6.5-8.5. when sludge is too acidic, it is planned to counteract it witgh the $\mathrm{Ca}(\mathrm{OH})_{2}$ solution. 
The determination of heavy metals ' concentrations in sewage sludge: samples of sewage sludge for determination of heavy metals' concentrations is taken every 10 days. Then they are burned (samples are burned about 3 hours at $450{ }^{\circ} \mathrm{C}$ temperature). Then the burned samples are mineralized $-0.5 \mathrm{~g}$ of burned sewage sludge is poured with $12 \mathrm{ml}$ of concentrated nitric acid (HNO3) and $2 \mathrm{ml}$ of hydrogen peroxide acid H2S2. Then the sample is meneralized in a mineralizator for about an hour at $200{ }^{\circ} \mathrm{C}$ temperature. After mineralization the sample is cooled to $70-50{ }^{\circ} \mathrm{C}$ and filtered through a glass filter into a $50 \mathrm{ml}$ flask and solution is deluted with destilled water. Then heavy metals ${ }^{6}$ concentrations are measured by tomic absorption sperctrometer Buck Scientific 210 VGP.

The determination of heavy metals' concentrations in earthworms' body tissues: 20 adult earthworms are selected randomly and they are washed with distilled water to remove traces of compost and mucus and weighed. Samples are placed to the plates and left for 24 hours at $15{ }^{\circ} \mathrm{C}$ that inorganic fraction residues would be removed from earthworms ${ }^{\circ}$ bodies. Then they are placed in a low temperature environment (in the refrigerator, where the temperature is less than $0{ }^{\circ} \mathrm{C}$ ) for organisms to die. Then the sample are burned and concentrations of heavy metals are measured in the same method as in sewage sludge.

\section{Results and discussion}

Within 120 days of vermicomposting heavy metals concentrations have decreased. Earthworms can bio-accumulate high concentrations of metals including heavy metals in their tissues without affecting their physiology and this particularly when the metals are mostly non-bioavailable.

Chromium, cadmium and nickel concentrations in sewage sludge measurement results are presented in Fig. 2, 3, 4. As can be seen from the data, the amount of chromium in sewage sludge during vermicomposting has decreased. The heavy metal's concentration in the 120-day process has decreased about three times in comparison with the initial concentration. From the initial concentration, which was $284.48 \mathrm{mg} / \mathrm{kg}$, concentration of chromium in sewage sludge decreased $92.62 \mathrm{mg} /$ $\mathrm{kg}$ - up to $191.79 \mathrm{mg} / \mathrm{kg}$.

Concentration of cadmium in sewage sludge decreased 1.5 times. The decrease of concentration of cadmium was most intense for the first 40 days of the vermicomposting. Initial metal concentrations in sewage sludge from $181.55 \mathrm{mg} / \mathrm{kg}$ in 40 days decreased to $131.68 \mathrm{mg} / \mathrm{kg}$. During the rest of the vermicomposting process time concentration of this metal has decreased to $120.8 \mathrm{mg} / \mathrm{kg}$.

Concentration of nickel in the sewage sludge decreased $55.5 \mathrm{mg} / \mathrm{kg}-$ from $140,39 \mathrm{mg} / \mathrm{kg}$ to $84.89 \mathrm{mg} / \mathrm{kg}$. Metal's concentration decreased by more than one and a half times -1.65 . As can be seen from Figure 4 , the concentration of nickel decreased in a similar intensity durnig the whole process.

Figure 1 contains the chart of concentrations of heavy metals changes in sewage sludge and in earthworms ${ }^{6}$ body tissues. $92.69 \mathrm{mg}$ of chromium metal was removed from $1 \mathrm{~kg}$ of sewage sludge. Compared with the initial concentration, 33.5 percent of chromium has been removed from the sewage sludge. During the same period cadmium was mostly accumulated in earthworms ' body tissues. It was $119.55 \mathrm{mg} / \mathrm{kg}$ of chromium bioaccumulated in earthworms ${ }^{6}$ body tissues. $60.75 \mathrm{mg} / \mathrm{kg}$ of cadmium was removed from the sewage sludge. In 120 days of the experiment $50.48 \mathrm{mg} / \mathrm{kg}$ of nickel was bioaccumulate in earthworms' bodu tissues, and $55.5 \mathrm{mg}$ was removed from 1 kilogram of sewage sludge.

In Figures 2, 3 and 4 are graphically represented concentrations of chromium, cadmium and nickel changes in sewage sludge and earthworms' body tissues. With the decreasing amount of heavy metals in sewage sludge the concentration in the earthworms' body tissues increased.

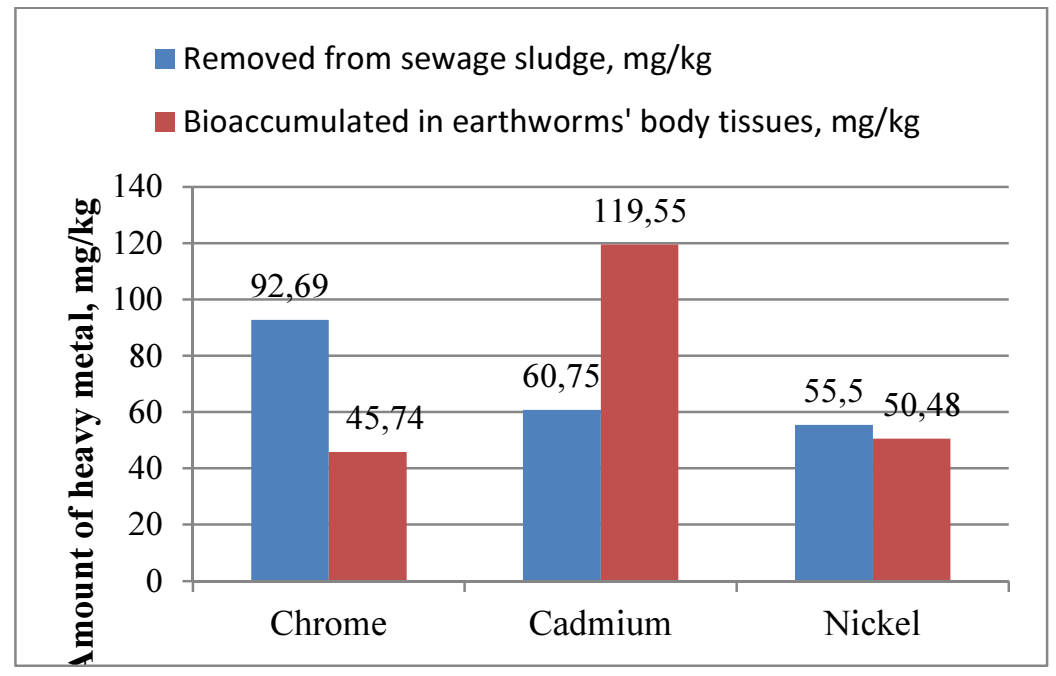

Fig. 1. Changes in the concentrations of heavy metals in sewage sludge and earthworms after 120 days of vermicomposting, $\mathrm{mg} / \mathrm{kg}$ 


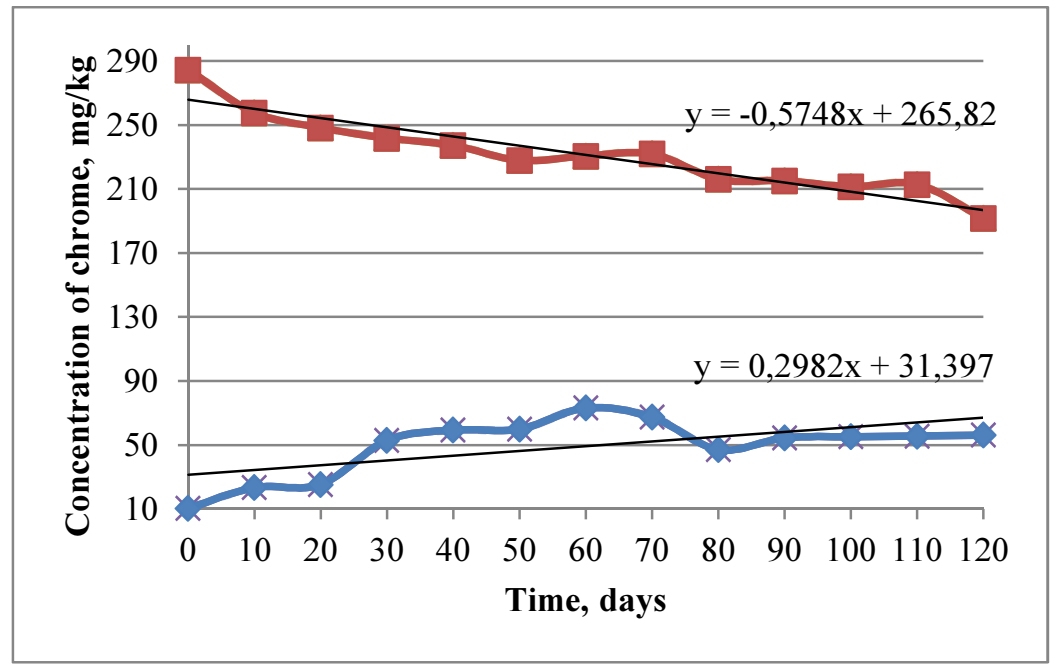

Fig. 2. Chromium concentrations in sewage sludge and earthworms change comparison

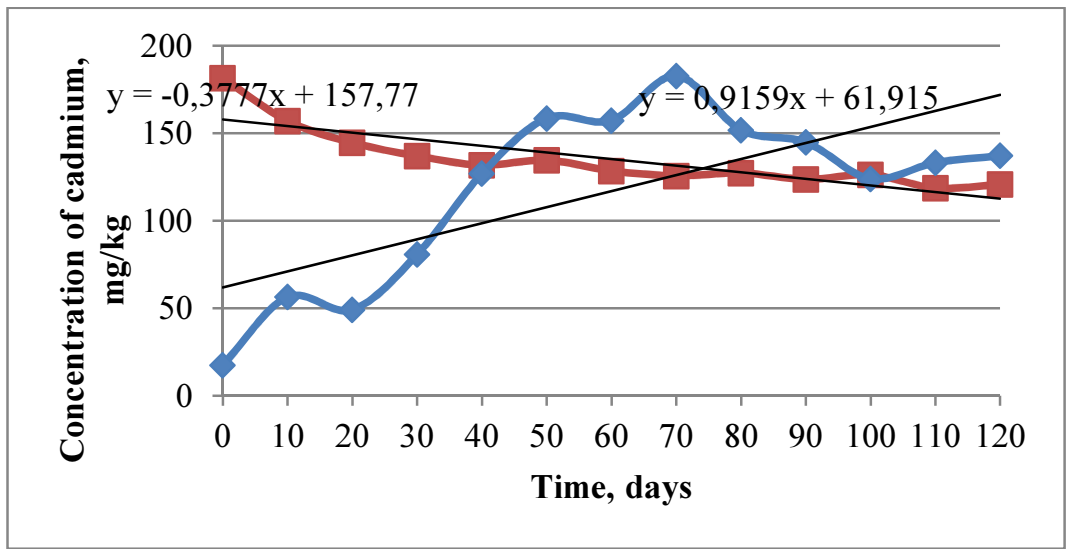

Fig. 3. Cadmium concentrations in sewage sludge and earthworms change comparison

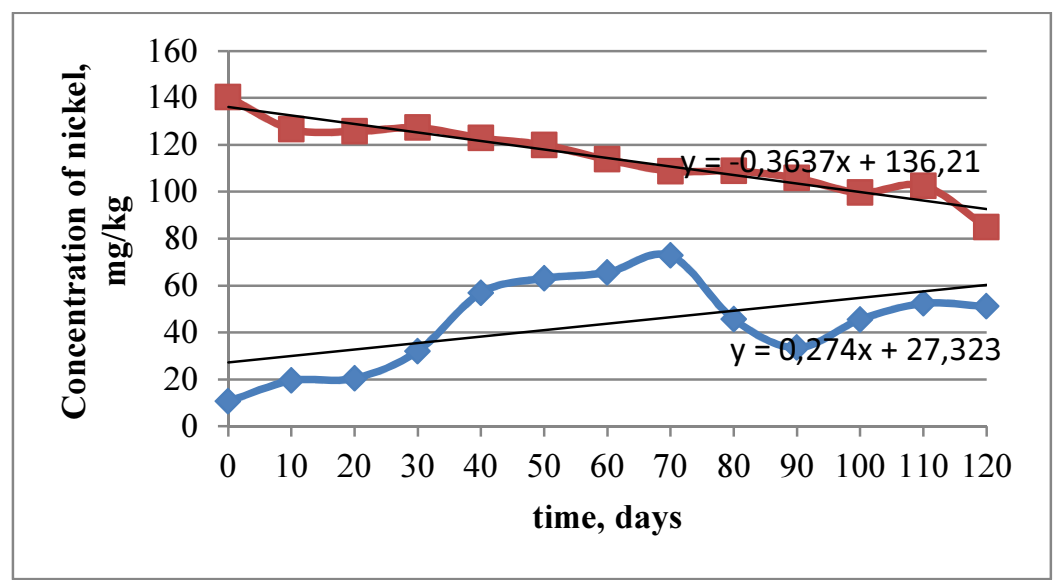

Fig. 4. Nickel concentrations in sewage sludge and earthworms change comparison

Heavy metals in earthworms after the experiment are distributed as follows: $\mathrm{Cd}>\mathrm{Ni}>\mathrm{Cr}$. The results show that most bioaccumulated metal in earthwormswas cadmium. In 120 days of vermicomposting at least bioaccumulated chrome. Removed amount of metals from the sewage sludge are distributed as follows: $\mathrm{Cr}>\mathrm{Cd}>\mathrm{Ni}$.

Shahmansouri [14] investigated the heavy metal bioaccumulation in Iranian and Californian earthworms during the process of vermicomposting sewage sludge. These studies have found that heavy metals $\mathrm{Cr}$, $\mathrm{Cd}$ concentrations in vermicompost decreases over time, and both types of earthworms increases. According to researcher, the Californian earthworms have been better accumulated heavy metals. Of all these metals mainly chromium metal was bioaccumulated in earthworms, slightly less - cadmium. N. M. Aleagha [9] in his vermicomposting study found that during the first 14 days high concentrations of heavy metals $(\mathrm{Cr}, \mathrm{Ni}, \mathrm{Cd})$ bioaccumulation levels were achieved. 
Heavy metals $(\mathrm{Cd}$ and $\mathrm{Ni})$ concentrations in earthworms during vermicomposting process demonstrate the ability of Californian earthworms to bioaccumulate these contaminants. $\mathrm{Cd}$ and Ni bioaccumulation in earthworms occurs in a linear relationship between the amount of metal in earthworms and time [12].

Singh and Kalamdhad [15], after a sewage sludge vermicomposting studies found that California earthworms for their physiological metabolic specificities can accumulate high concentrations of heavy metals in non-toxic forms.

A Begum [13] found that within 60 days (December-January) of vermicomposting sewage sludge using Californian earthworms 69.9 percent compared with initial amount of $112 \mathrm{mg} / \mathrm{kg}$ chromium was removed. In her studies, sewage sludge was mixed in various proportions with vandnes hyacinth.

Also, researching heavy metals in sewage sludge, A. B. Azizi [16] found that vermicomposting sewage sludge (by mixing it with the mushroom compost) after 10 weeks from the initiation of $\mathrm{Cr}$ and $\mathrm{Cd}$ concentrations compared to the original sewage sludge decreased from 90 to 98.0 percent.

The worms' digestive system is apparently capable of detaching heavy metal ions from the complex aggregates between these ions and humic substances in the waste as it rots. Various enzyme-driven process then seem to lead to assimilation of the metal ions by the worms so that they are locked up in the organism's tissues rather than being released back into the compost as worm casts. The separation of dead worms from compost is a relatively straightforward process allowing the heavy metal to be removed from the organic waste.

\section{Conclusion}

The objective of the study was to evaluate the heavy metals $(\mathrm{Cr}, \mathrm{Ni}, \mathrm{Cd})$ disposal of sewage sludge and bioaccumulation of these substances in Californian earthworms.

Having analyzed the results of other studies, there can be stated that our experimental results confirm the efficiency of the Californian earthworms when removing heavy metals from sewage sludge. Studies have shown that when vermicomposting sewage sludge, a large amount of heavy metals bioaccumulate in earthworms' body tissues, while $\mathrm{Cr}, \mathrm{Ni}$, $\mathrm{Cd}$ concentrations in sewage sludge decreases.

\section{References}

[1] Baltrėnas, P.; Butkus, D.; Vasarevičius, S.; Oškinis, V.; Zigmontienè, A. 2008. Aplinkos apsauga. Vilnius: Technika. 14-125 psl.

[2] Jackel, U.; Thummes, K.; Kampfer, P. 2005. Thermophilic methane production and oxidation in compost, Federation of European Microbiological Societies. Microbiology ecology 52: 175-184.

[3] Suthar, S.; Singh, S. 2008. Vermicomposting of domestic waste by using two epigeic earthworms (Perionyx excavatus and Perionyx sansibaricus), International Journal of Environmental Science and Technology 5(1): 99-106. ISSN 1735-1472;

[4] Frank, R.; Klauck, C.; Stonefield, K. I. 1983. Metal Transfer in Vermicomposting of Sewage Sludge and Plant Wastes, The Bulletin of Environmental Contamination and Toxicology 31: 673-679. Sreenivas C, Muralidhar, S. Rao, M.S. 2000. Vermicompost, a viable component of IPNSS in nitrogen nutrition of ridge gourd, Annals of Agricultural Research 21(1):108-113.

[5] Barałkiewicz, D.; Siepak, J. 2001. Slurry sampling for electrothermal atomic absorption spectrometric determination of chromium, nickel, lead and cadmium in sewage sludge, Analytica Chimica Acta. 437: 11-16. http://dx.doi.org/10.1016/S0003-2670(01)00979-5

[6] Lekeshmanaswamy, M.; Yasotha, D. 2012. Vermitechnology - an Eco-biological Tool for Management of Solid Wastes, with Special Reference to Pressmud, Sludge and Cowdung, Indian Journal of Natural Sciences 11(11): 864-964. ISSN 0976-0997.

[7] Singh, N. B.; Khare, A. K.; Bhargava, D. S.; Bhattacharya, S. 2004. Optimum Moisture Requirement during Vermicomposting Using Perionyx excavatus. Applied ecology and environmental research . 2(1): 53-62.

[8] Nagavallemma, K. P.; et. al. 2004. Vermicomposting: Recycling Wastes into Valuable Organic Fertilizer, iš Global Theme on Agrecosystems Report 8: 17 .

[9] Aleagha, M.; et. al. 2011. Bioaccumulation of Heavy Metals by Iranian Earthworm (Eisenia fetida) in the Process of Vermicomposting, American Eurasian Journal of Agriculture \& Environment Science 5(4): 480-484.

[10] Pattnaik, S.; Reddy, W. 2011. Heavy metals remediation from urban wastes using three species of earthworm (Eudrilus eugeniae, Eisenia fetida and Perionyx excavatus), Journal of Environmental Chemistry and Ecotoxicology 3(14): 345-356.

[11] Jamaludin, A. A.; Mahmood, N. Z. 2010. Effects of Vermicomposting Duration to Macronutrient Elements and Heavy Metals Concentrations in Vermicompost, Sains Malaysiana 39(5): 711-715.

[12] Aleagha, M.; Pedram, M.; Omrani, G. 2009. Bioaccumulation of Heavy Metals by Iranian Earthworm \{Eisenia fetida) in the Process of Vermicomposting, American - Eurasian Journal of Agriculture and Environment Science 5(4): 480-484. ISSN 1818-6769.

[13] Begum, A.; Krishna, H. 2010. Management of Municipal sewage sludge by vermicomposting technique, International Journal of ChemTech Research 2(3): 1521-1252. ISSN : 0974-4290.

[14] Shahmansouri, M. R.; Pourmoghadas, H.; Parvaresh, A. R.; Alidadi, H. 2005. Heavy Metals Bioaccumulation by Iranian and Australian Earthworms (Eisenia fetida) in the Sewage Sludge Vermicomposting, Journal of Environmental Heath Science and Engineering 2(1): 28-32.

[15] Singh, J.; Kalamdhad, A. S. 2012. Reduction of Heavy Metals during Composting- A Review, International Journal of Environmental Protection 2(9): 36-43.

[16] Azizi, A. B. 2012. Vermiremoval of heavy metal in sewage sludge by utilising Lumbricus rubellus, iš Ecotoxicology and Environmental Safety. [interaktyvus]. [žiūrèta 2013 sausio 14 d.]. Prieiga per internetą: http://www.ncbi.nlm.nih.gov/nlmcatalog?term=\%22Ecotoxicol+Environ+Saf\%22[ Title +Abbreviation]; ISSN 0147-6513;

[17] Shaymaa, M.; et. al. 2010. Removal of Aliuminium, Lead and Nickel from Industrial Sludge via Vermicomposting Process, World Applied Science Journal 10(11): 1296-1305. ISSN $1818-4952$. 